\title{
Optimization of Logistics Services in Vietnam Through LOGIVAN Application
}

\author{
Cong Vu Van ${ }^{1 *} \quad$ Hoa Phuong Tran ${ }^{2} \quad$ Thi Ngoc Hoa Le ${ }^{1} \quad$ Thi Kim Lien Hoang ${ }^{1}$ \\ 1.University of Economics - The University of Danang, No.71 Ngu Hanh Son Street, Ngu Hanh Son District, \\ Danang City, Vietnam \\ 2.Ho Chi Minh National Academy of Politics, No.135 Nguyen Phong Sac Street, Cau Giay District, Hanoi City, \\ Vietnam \\ * E-mail of the corresponding author:vuvc@due.edu.vn
}

\begin{abstract}
Logistics is a type of service that plays an important role in promoting the country's economic growth. In addition, it is also of great significance to the transport sector in Vietnam in dealing with the challenges of traffic congestion in large cities. In Vietnam today, logistics services are growing. However, there is one major limitation that still exists, that is freight costs are still high. This does not meet the best requirements of customers. There are many reasons for this problem, one of the reasons is that trucks only carry one-way cargo, but there are no goods to ship backwards. The paper studies the application of LOGIVAN smart transport model in developing Logistics services in Vietnam today. Research results show that LOGIVAN transport model is the optimal model in solving the problem of empty cars in the transport of goods when they go back to the place of departure. This helps minimize Logistics costs for businesses, increases income for drivers and leads towards sustainable transport development. LOGIVAN develops two platform solutions for goods owners and vehicle owners. Accordingly, the author of the article confirms the quality of this model in developing Logistics services in Vietnam and guide the operation for users via applications on personal mobile devices at the same time.
\end{abstract}

Keywords: Logistics; LOGIVAN; Vietnam.

DOI: $10.7176 / \mathrm{JESD} / 10-14-01$

Publication date:July $31^{\text {st }} 2020$

\section{INTRODUCTION}

Decision No. 200/QD-TTg of the Prime Minister of Vietnam on February 14, 2017, approving the action plan to enhance competitiveness and develop Vietnam's logistics service until 2025, has confirmed: Currently, Logistics accounts for a significant proportion in the overall structure of the national economy. It plays a supporting role, connects and promotes socio-economic development of the whole country, as well as contributes to the improvement of the competitiveness of the economy [1]. Especially, in the field of transportation, the optimization of transport and logistics development in a smart way can help reduce vehicle traffic in product distribution and solve some challenges about serious traffic congestion in some large cities in Vietnam. Therefore, Logistics is a service industry with great economic and social significance. The application of modern science and technology contributes to the increasing of labor productivity in the field of Logistics. This gradually develops and affirms the position of Vietnam Logistics service, which is a very necessary requirement.

Recently, there are many research works of domestic and foreign scientists about Logistics development and some related issues such as: Developing Logistics service in Vietnam by Pham Trung Hai (2019); Development trend of Logistics in Vietnam in the Industrial Revolution 4.0 by Pham Hong Nhung (2019); A supply chain assessment of logistics development drivers of South Eastern Nigeria by Chinedum Onyemechi (2019); Logistics management requirements and logistics performance efficiency: the role of logistics management practices evidence from Egypt by Hend Medhat Amin; Tamer Mohamed Shahwan (2020)... Works that show new research results specialize in scientific and technological solutions in developing Logistics services. However, no scientific work has clearly analyzed the status of Logistics in Vietnam from which to discuss in depth the application of LOGIVAN smart transport model in the development of Vietnam Logistics. Therefore, the author chooses a specific solution on applying LOGIVAN transport model as a research problem.

The objective of this paper is to analyze the benefits of LOGIVAN, then the author recommends applying LOGIVAN smart transport model in developing Logistics services sector in Vietnam.

The paper uses analytical research methods, aggregates secondary data source, synthesizes reviews on LOGIVAN model from experts. At the same time, the author performs operations directly on the application model, thereby, re-evaluates the problem and applies it.

\section{CONTENT}

\subsection{Some theoretical issues about Logistics services}

Recently, Logistics has gradually affirmed its important role, and has become a key economic sector in the economies of many countries. Currently in the world, it can be said that there are many definitions of Logistics. 
According to the Logistics Management Board of the United States (Counseling of Logistics Management, 1991), Logistics is the process of planning, organizing, implementing and controlling effectively in terms of cost of process of material flow and storage, semi-finished products and finished products with relevant information from the starting point of the production process to the final destination for the purpose of meeting customer requirements [2].

According to the United Nations, Logistics is the activity of managing the process of transferring raw materials through the stages of storage, producing products to consumers as required by customers.

At the 7th session, Session XI, the National Assembly of the Socialist Republic of Vietnam on June 14, 2005 passed the 2005 Commercial Law, which specifies the concept of Logistics services. Article 233 - Section 4 Chapter VI of the Commercial Law of June 14, 2005, provides for "Logistics services are commercial activities whereby traders organize one or more of the stages involved pick up goods, transport, warehousing, storage, customs clearance, other paperwork, customer advice, packaging, coding, delivery, or other related services to the goods as agreed with the customer to receive remuneration" [3].

Thus, through the definitions of Logistics, we can see that Logistics plays an important role in production, circulation and distribution of goods. It helps manufacturers to promptly and accurately capture customers' needs, boosting the flow of goods, cash flow and information from suppliers, factories, transporters, warehouses through wholesale and retail distribution channels to end consumers more smoothly. In addition, Logistics also helps to reduce costs, satisfy customer needs and improve brand awareness of businesses.

Determining that importance, many countries already had logistics development plans and strategies. Specially, in the context of the fourth industrial revolution with more and more profound influence, Logistics in many countries has been raised to a new level. Logistics in the period of Industrial Revolution 4.0 (logistics 4.0) is a technological consolidation, eliminating the boundaries between physical, digital and biological fields, bringing a combination of virtual systems and entity. Achievements in the field of artificial intelligence (AI), integrating artificial intelligence with the Internet of Things (IoT) and modernization tools will change the whole perspective of the warehouse system and distribution of goods. In logistics activities, the Industrial Revolution 4.0 will also strengthen the connection of devices such as pallets, cranes, freight trailers ... to the Internet.

Many logistics companies around the world are starting to equip modern tools such as: Serving robots in modern warehouses; Unmanned aircraft; Autonomated guided vehicles (AGV); smart forklifts; navigation devices using WiFi, Bluetooth; Smart mobile phones participate directly in the work process; radio wave format system (RFID); barcode scanning application; inventory optimization based on cloud computing; integration of service contracts, order management, customer relations in Logistics; Blockchain technology application...

Within the scope of the article, the author mentions LOGIVAN smart transport model which is being implemented in Vietnam - the appilcation of technology to solve the problem of empty cars, contributing to reducing $30 \%$ of Logistics costs for businesses and increasing driver incomes.

\subsection{Actual situation of Logistics in Vietnam today}

Vietnam is considered a country with great potentials and opportunities to develop Logistics services both on land, sea and air. As a country stretching along the North-South axis, the land border is $4,550 \mathrm{~km}$ long, bordering China in the North, Laos and Cambodia in the West [4], Vietnam has the advantage in the development of Logistics services in Southeast Asia. Specially, with the advantage of being located on the maritime transport axis, the East is bordered by the East Sea, Vietnam has favorable conditions to become a transshipment center for international marine freight transport.

In addition, Vietnam currently possesses some great potential to develop Logistics services such as: road transport infrastructure systems, airports, seaports, warehouses, trade infrastructure, logistics centers which are constantly expanded on a large and widespread scale. Besides, the accompanying services have been promptly responding to the very diverse requirements of the domestic and regional Logistics market. Customs clearance procedures for exports have also improved significantly. As a result, in recent times, along with the development of other industries in the Vietnamese economy, Logistics has also made great progress with great growth potential.

Joining the Vietnam Logistics market, according to the data published in VLA 2018 White Paper Logistics, if in 2016 the number of Logistics service enterprises in Vietnam was 22,366, by 2018, this figure would be about 30,971 enterprises respectively, an increase of 30\% [5]. Currently, 30 transnational logistics service providers are operating in Vietnam with big names such as: DHL, FedEx, Maersk Logistics, APL Logistics, CJ Logistics, KMTC Logistics... [6]. By business sectors, Logistics enterprises in Vietnam are classified into 4 types. 
Table 1. Classification of Logistics service enterprises by business sector

\begin{tabular}{|c|l|}
\hline Number & \multicolumn{1}{c|}{ Type of business } \\
\hline 1 & Transport operation enterprises: Transportation services (road, sea, air) \\
\hline 2 & Enterprises exploiting infrastructure at the nodes (ports, airports, stations ...) \\
\hline 3 & Enterprises exploiting loading and unloading warehouses and Logistics services \\
\hline 4 & $\begin{array}{l}\text { Freight forwarding service business, transport agents, shipping agents, customs clearance agents, } \\
\text { 3PLs and other businesses such as Logistics software solutions, consulting and inspection, financial } \\
\text { checks }\end{array}$ \\
\hline
\end{tabular}

Source: Author synthesized according to Vietnam Logistics Report 2017 - Ministry of Industry and Trade

In recent years, Vietnam's logistics capacity has gradually been improved and achieved many positive results. According to statistics of the World Bank (World Bank) in 2018, Vietnam's logistics industry currently has a growth rate of $16 \%$ per year and is expected to continue to grow in the coming years. LPI report (Logistics Performance Index - the index evaluating Logistics performance) in the publication "Connecting to complete 2018" of World Bank in 2018, Vietnam's ranking increased by 25 places to 39/160. Accordingly, Vietnam surpassed at $39^{\text {th }}$ rank with a significantly improved LPI score of 3.27 , the highest in 6 rankings, ranked $3^{\text {rd }}$ place in ASEAN, after Singapore ranked $7^{\text {th }}$ and Thailand ranked $32^{\text {th }}$. Average LPI of Vietnam over the years from 2012, 2014, 2016, 2018 World Bank reports is currently ranked 45/167 countries [7]. According to the Vietnam Association of Logistics Services Enterprises (VLA), the scale of Vietnam's logistics market has been constantly increasing with the rapid growth of import and export turnover over the past years, reaching about 40-42 billion USD/year. In 2019, Vietnam's logistics service has a relatively high growth rate, reaching 12-14\%; the percentage of enterprises outsourcing Logistics services is about $60-70 \%$, contributing about $4-5 \%$ of GDP. The Government set a target that by 2025 , the proportion of logistics service industry in GDP will reach $8 \%-10 \%$, the growth rate of services will reach $15 \%-20 \%$, the proportion of outsourcing logistics services will reach $50 \%$. $-60 \%$, Logistics costs go down [8].

Determining the important role of Logistics in the national economy in general and in the field of Transport in Vietnam in particular, the Government has issued a number of legal documents clearly showing its commitment to support and create a favorable environment for the purpose of improving competitiveness and developing Vietnam Logistics service. On January 22, 2014, the Prime Minister issued Decision No.169/QD-TTg approving the Project on Development of Logistics Services in Vietnam's Transport Sector to 2020, with orientations to 2030. Accordingly, the general purpose of the project is developing Logistics services in Transport field, in order to enhance economical effect in Transport operation; contributing to the success of Vietnam Sea Strategy by 2020. On February 14, 2017, the Prime Minister issued Decision No.200/QD-TTg on Approving the action plan to enhance Vietnam's competitiveness and develop Logistics services to 2025. Among them, 6 viewpoints on developing Logistics services of the Decision are: (1) Logistics is an important service industry in the overall structure of the national economy; (2) Logistics becomes a service industry that brings high added value; (3) Developing a healthy Logistics service market; (4) Maximize the advantages of strategic geographic location to become an important Logistics hub in the region; (5) Improve the competitiveness of enterprises providing Logistics services. To develop enterprises providing Logistics services in terms of quantity, size, human resource, and high competitiveness in domestic and international markets; (6) The State plays a supporting role, creating a favorable environment. On July 6, 2018, the Prime Minister signed Decision No.27/2018/QD-TTg promulgating the Vietnam Economic Sector System and this is the first time Vietnam has its own Logistics industry code (Code 52292: Logistics). On July 18, 2018, the Prime Minister signed the Directive No.21/CT-TTg on promoting the implementation of solutions to reduce logistics costs, effectively connect transport infrastructure...

Thus, the close attention and appreciation of the Government to the Logistics service industry shows that Logistics is a very important sector of Vietnam's economy. And both short-term and long-term strategies are required to develop Logistics services in the coming time. Inheriting the development of science, technology, application of artificial intelligence in the field of Logistics, transport optimization is also an important factor contributing to the development of Logistics services in Vietnam.

\subsection{Applying LOGIVAN smart transport model in developing Logistics services in Vietnam today 2.3.1. LOGIVAN application}

LOGIVAN application is a technology solution that provides transport services 4.0 based on the direct connection of goods owner and empty truck network nationwide. LOGIVAN application helps businesses search and manage trucks online. At the same time, it helps truckers increase their income by up to $30 \%$.

Established in September 2017, LOGIVAN's mission is to digitize the trucking industry, providing a highquality automated integration system that saves logistics costs for all Vietnamese businesses. In March 2018, LOGIVAN won the Uber Exchange start-up contest, the only start-up to win a ticket to Silicon Valley, USA and received direct advice from UBER Global Chief Technology Officer - Thuan Pham. By April 2018, LOGIVAN successfully raised US \$600,000 from Insignia Ventures Partners. It began to expand operations in Ho Chi Minh 
City and other major economic centers in Vietnam, serving companies with high transportation needs. In July 2018 , LOGIVAN won the Best Startup Company in PITCH 2018 at RISE 2018. Overcoming more than 800 teams from around the world, LOGIVAN won the first victory for Vietnamese startups at the Asia Technology Summit. In August 2018, LOGIVAN invested an additional \$1.75 million in Series A round led by Ethos Partners, Insignia Venture Partners and VinaCapital Ventures. From here, LOGIVAN continued to upgrade technology products to serve the needs of freight business and facilitate transparency in truck tracking and management. In December 2018, LOGIVAN won the First Pitch@Palace Global 2018 organized by Prince Andrew - Duke of York. In addition to providing a breakthrough solution in the field of Logistics, LOGIVAN is also praised by the Award Council for having a positive impact on the society, economy and living environment in Vietnam. In February 2019, LOGIVAN successfully called for US \$5.5 million from Alpha JWC and other reputable Asian investors. With this investment, LOGIVAN aims to analyze and integrate data to increase supply chain efficiency, expanding the network of 40,000 transport partners with hundreds of orders per day.

In mid-2019, the Prime Minister's Decision No.703/QD-TTg on the application of transportation technology to improve service quality and reduce logistics costs in total GDP has become a driving force for LOGIVAN to continue proving its role. LOGIVAN has launched an apple (automatic pricing function for LOGIVAN: Code E), reel (a system suggested by the field of machine learning based on artificial intelligence) pricing system and integrated into the 5-star LOGINOW package. On October 21, 2019, LOGIVAN officially launched the LOGINOW booking service, which helped shippers get instant quotes and $100 \%$ have cars and many other outstanding utilities. With LOGINOW, the goods owner will be directly quoted and have drivers arranged for the order by LOGIVAN. LOGINOW rates are not only displayed immediately for all routes, but also good and competitive in the market thanks to LOGIVAN's modern quotation system. From there, it helps shippers look up prices quickly and accurately with the best freight for all shipping routes, contributing to saving time and reducing costs for businesses' Logistics.

Thus, with the application model of LOGIVAN technology, the goods owner will always find the most suitable car, no more complicated and time-consuming steps to find cars like the traditional way of finding cars before. There is no longer a situation where a car is canceled or a vehicle cannot be found. At the same time, LOGIVAN's staff will monitor and manage the entire shipment's itinerary. At the same time, the goods owner can also know the status of their goods by actively tracking the journey of vehicles displayed online on the LOGIVAN Goods owner application.

Specially, LOGINOW also has cargo insurance and contracting services to bring transparency and peace of mind to goods owner. Therefore, goods owner will no longer worry about the safety of goods when using the LOGINOW feature.

All shipments booked through the LOGIVAN application and LOGINOW usage are managed by a 5-star quality driver team selected by LOGIVAN. Only drivers with full information, professional working attitude, extensive shipping experience can receive LOGINOW orders. This helps minimize the risks when transporting goods, bringing peace of mind for shippers.

\subsubsection{Evaluate the effectiveness of the LOGIVAN model}

The author's research results show that, LOGIVAN transport model is a smart and efficient transport model, users will gain the great following benefits:

Firstly, minimizing logistics costs: LOGIVAN takes care of the whole process of searching for freight vehicles and transportation process. Businesses will save labor costs and simplify the transportation process.

Secondly, the benefits from LOGIVAN come from eliminating intermediaries in the supply chain, connecting goods owner' needs directly to sources of empty vehicles nationwide and helping vehicle owners increase their monthly income. The transport connection application is completely free. Drivers do not have to pay any costs when using LOGIVAN - Vehicle owners. Supporting quick orders, it is rated for increasing $30 \%$ income for drivers. If each delivery truck is ordered in the traditional way, you are paying $30 \%$ of the money for a service you do not use. It is a fact that not many people know. $30 \%$ of this cost is actually paid for the way back to the place of departure of the car because at that time the car was empty without goods. It is a serious waste for a car to return to its starting point without carrying any cargo. The car still consumes a significant amount of gasoline but does not optimize the transport capacity. Using LOGIVAN - transportation model applying technology and artificial intelligence in operation has become a "dual" solution. The goods owner do not have to pay $30 \%$ of the cost of turning and drivers take advantage of empty cars to return to increase income.

Thirdly, goods owner easily rent a cargo truck with just a few simple steps. Goods owner are quoted directly on the app and the costs are less than the market price. The vehicle owner can proactively negotiate shipping costs with the goods owner.

Fourthly, ensuring the safety: the LOGIVAN application displays the entire route map of the cart. Businesses easily grasp the status of their orders, limit late deliveries and worry about goods.

Fifthly, ensuring transparency: All transport activities are carried out by contract and full documentation. In addition, LOGIVAN still has the form of monthly debit to eliminate cumbersome payment process. 
Sixthly, with the breakthrough idea to take advantage of the empty direction of the vehicle, LOGIVAN contributes to reducing emissions from vehicles. As a result, it reduces the harmful effects of greenhouse gases and environmental pollution throughout the country.

In addition, using the service of LOGIVAN also helps to limit the amount of traffic on the road, avoiding traffic jams and accident risks. If LOGIVAN application is widely implemented, it will promote Vietnam's shipping industry in a sustainable manner.

Evaluating LOGIVAN application, some LOGIVAN logistics experts and big customers have many positive comments. Ms. Bui Truc Quynh, Director of HP Agriculture Company responded after using LOGIVAN: "LOGIVAN makes our transportation much more and more flexible, while ensuring quality and progress". Ms. Do Phuong Thao, Director of Thao Nguyen Company - Top 3 cashew exporters, top 500 large enterprises in Vietnam, said: "LOGIVAN is very easy to use and can find a truck much faster than calling the transportation parties". Mr. Ta Quoc Loi, Director of Logistics of Miwon Vietnam Co., Ltd. evaluated "LOGIVAN works professionally and youthfully. Miwon always receives support and coordination of LOGIVAN when arising, even on holidays" [9].

Thus, it can be said that LOGIVAN is an effective and suitable application for users in Vietnam.

\subsubsection{Manipulate LOGIVAN application}

LOGIVAN develops two transport technology products, LOGIVAN - Goods owner and LOGIVAN - Vehicle owner. Corresponding to the two technology products, the user is the owner of the goods and the owner of the truck will use two applications that suit his needs through mobile devices. In CH Play app of android devices, users can easily download the application. The interface of the application is simply identified.

Figure 1. LOGIVAN application interface-Goods owner and LOGIVAN-Vehicle owner

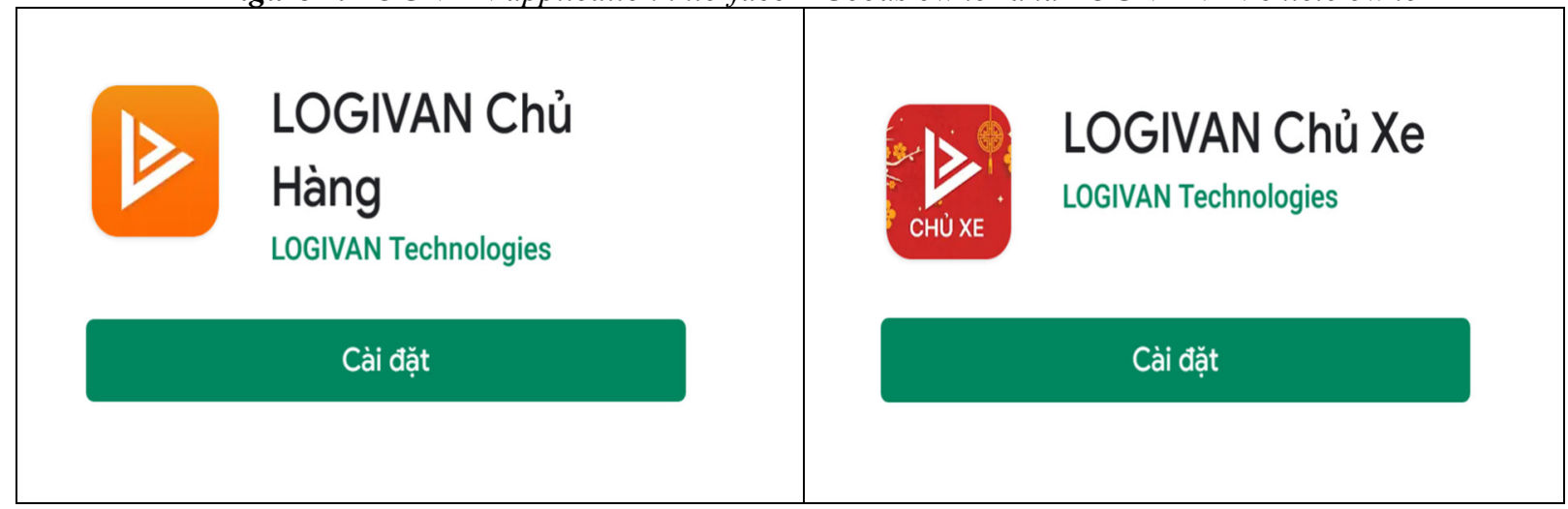

2.3.3.1. For goods owners

Source: Author made

After downloading the LOGIVAN Chủ hàng application to the machine, the owner of the goods proceeds to create a personal account. The steps to create an account are performed sequentially with simple operations: The owner only needs to register the current phone number, then enter full name then the account will be established. 
Figure 2. Register account for commodity owner
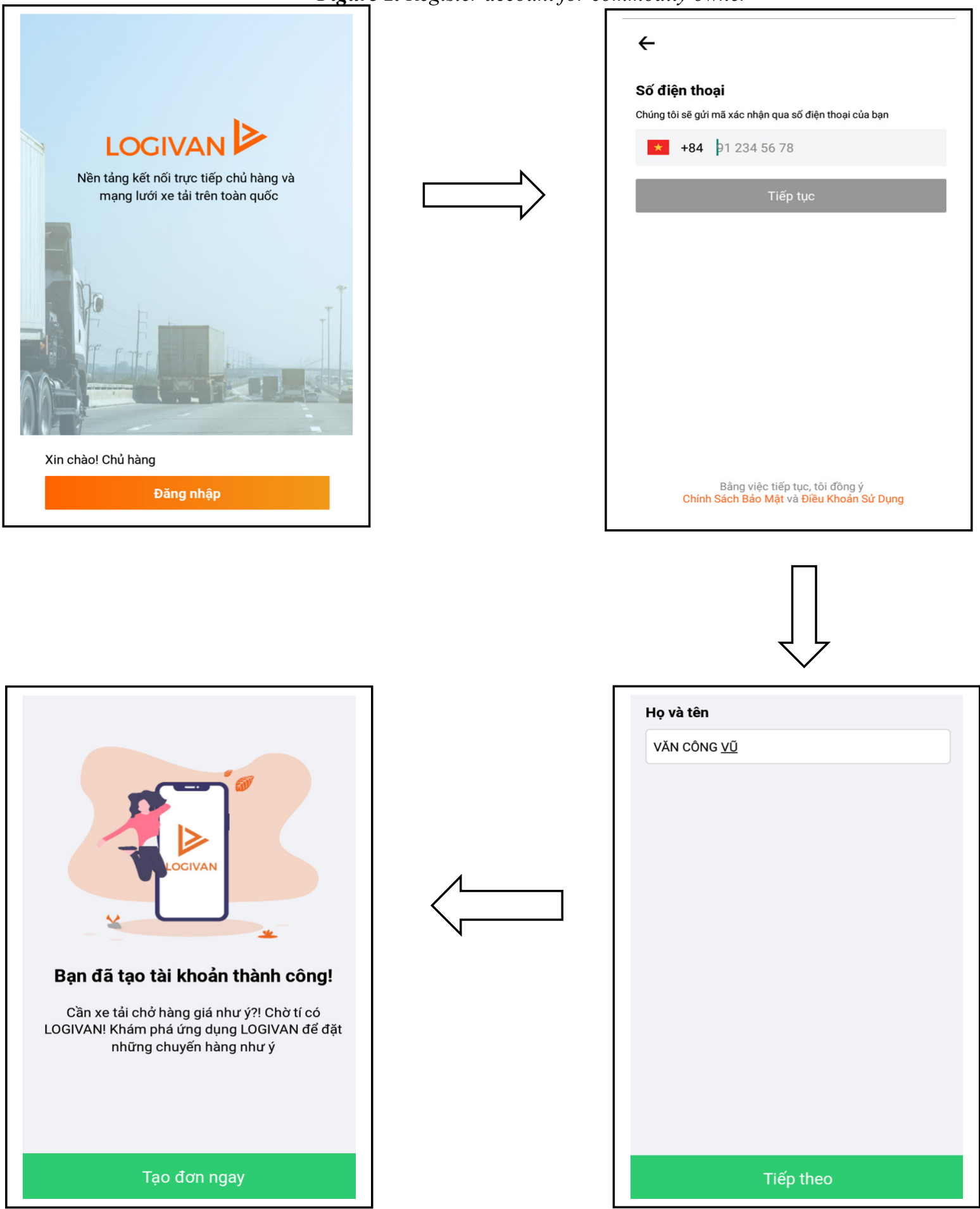

Source: Author made

After creating an account, the owner of the commodity can begin working on his or her transport needs. By entering the information: Shipping address (including the address of the goods to be transported and the address of the destination); Loading time; Name of goods and quantity of goods. The application will immediately display the best shipping price for owners. The price that the owner of the goods must pay is always the best price because this is a transport service on the return car, instead of no goods on the way back. 
Figure 3. The owner of the goods carries out the service on demand

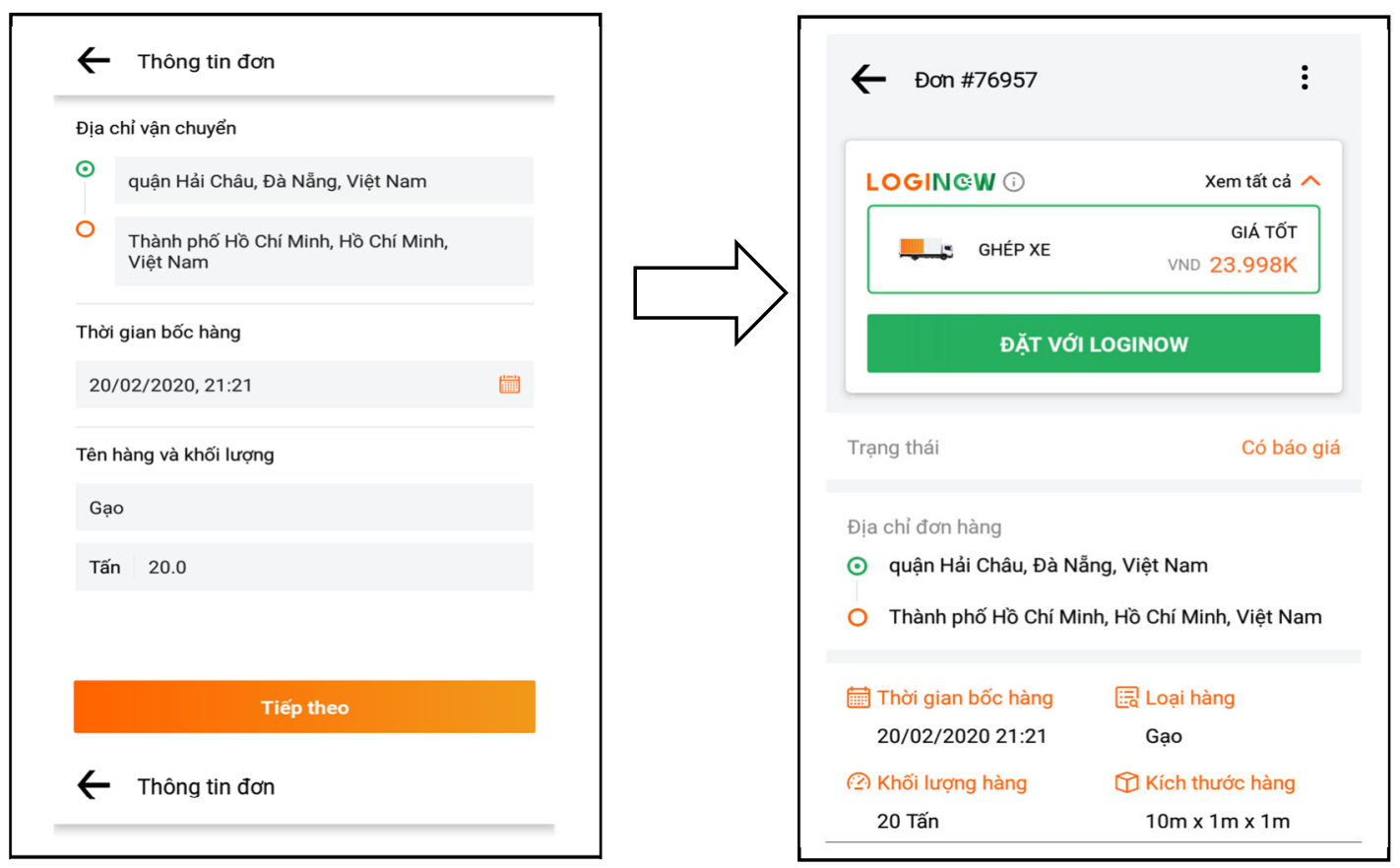

Source: Author made

After the completion of the order, if the owner of the goods wants to cancel the order for an objective or subjective reason, there is no need to continue using the service. It is possible to cancel an order by choosing one of the following reasons: No longer in need; order information changed; another car found; the type of vehicle or driver is inconsistent with the previous confirmation; the driver requires additional fees not included in the agreement; driver's attitude; driver arriving late at loading point; failure in communicating with the driver or distrust of the driver

2.3.3.2. For drivers with vehicles involved in transportation services

The driver will download the LOGIVAN Chu xe application to the phone, then proceed to register the user account. The account registration for the vehicle owner is more complete and more informative than for the owner of the goods with the purpose of creating trust with customers and management from LOGIVAN company. The driver will provide the following information: Phone number; first and last name; parking address; provinces that run often; Identity card; business license; transport license 
Figure 4. Account registration operation for Vehicle Owner
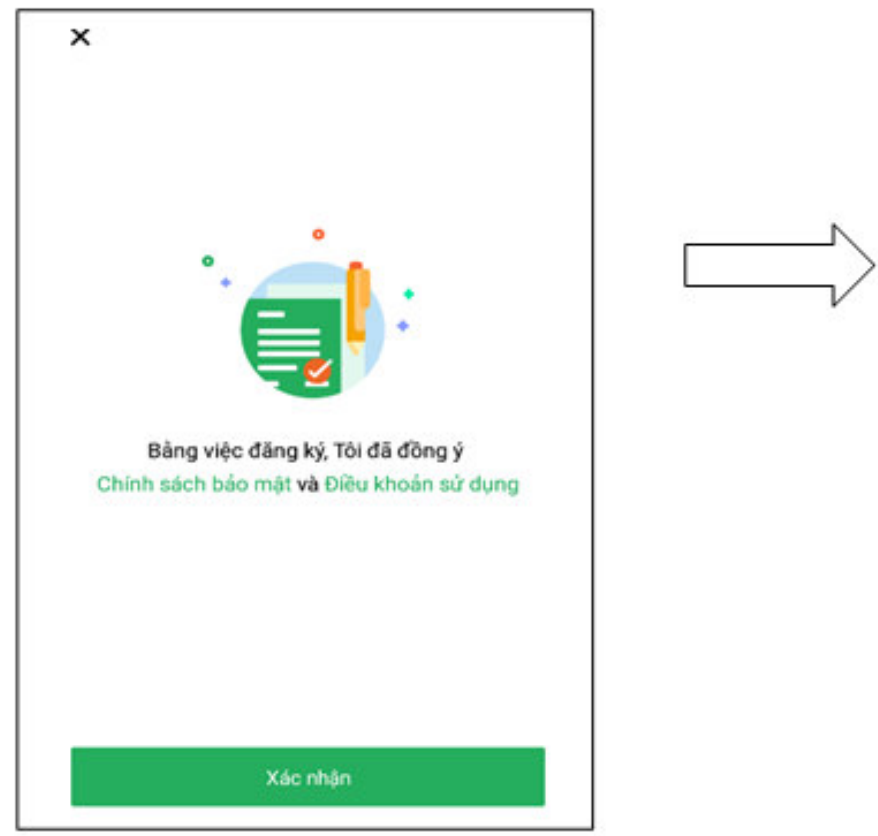

\section{$\leftarrow$ \\ Só điện thọ̣i}

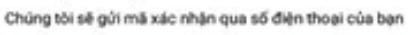

* +84 912345678
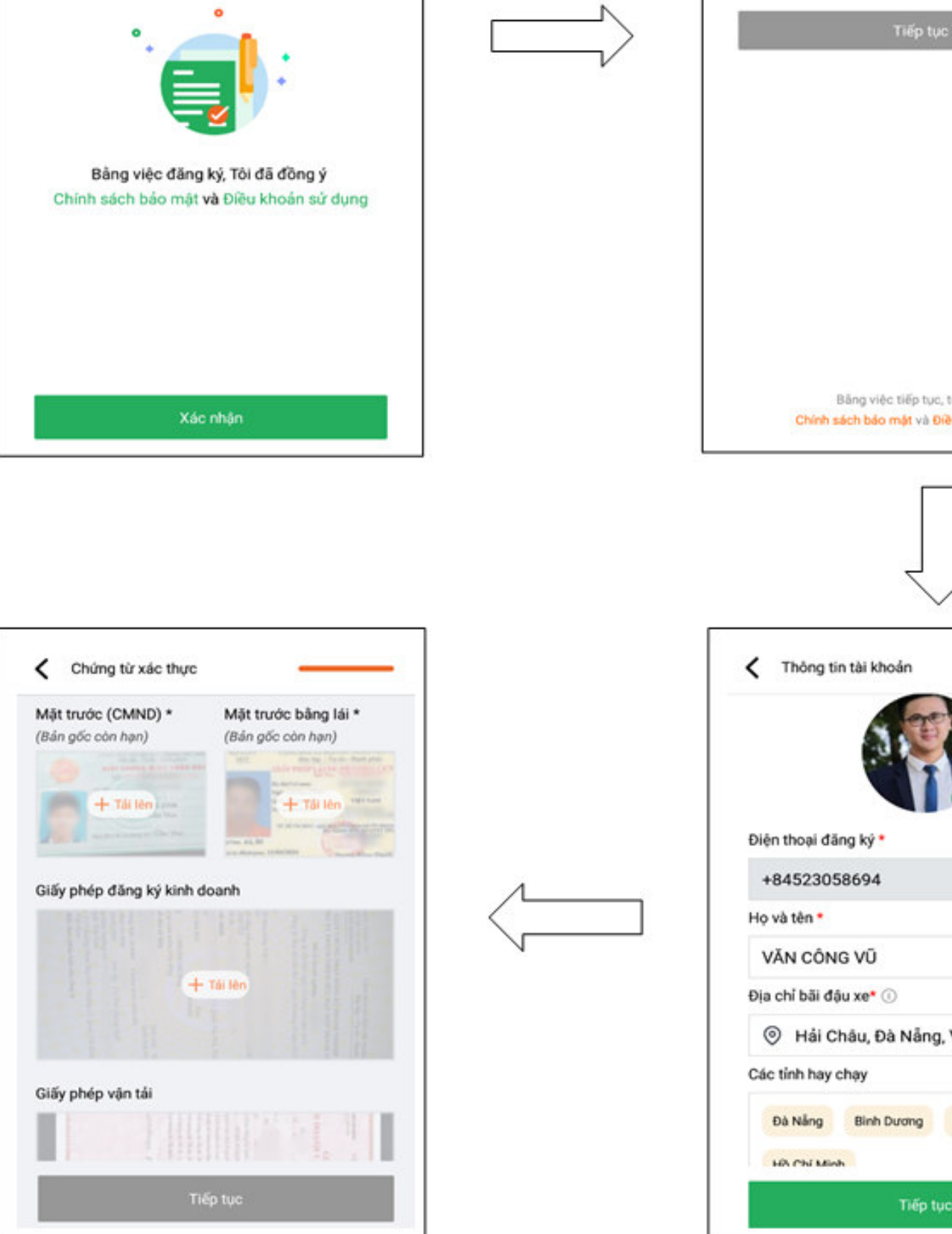

Điện thoại đăng $k \hat{y}$ *

$+84523058694$

Họ và tèn *

VĀN CÔNG Vū

Địa chi băi đậu xe** (1)

○ Hải Châu, Đà Nång. Việt Nam $\quad \rightarrow$

Cac tinh hay chạy

Da Ning Binh Dưong Ha Nöi $\rightarrow$

Ha moivents.

Source: Author made

After signing up for an account, the driver can start accepting shipments according to customer needs. Orders will appear on the vehicle owner's app with information about the location, time, type of goods, customer contact information. With the policy and model of LOGIVAN, the vehicle owner has the right to receive or not to receive shipments to suit his transport needs. If the driver accepts the order, he or she will announce the fee to customers. 
Figure 5. The vehicle owner performs the return freight service

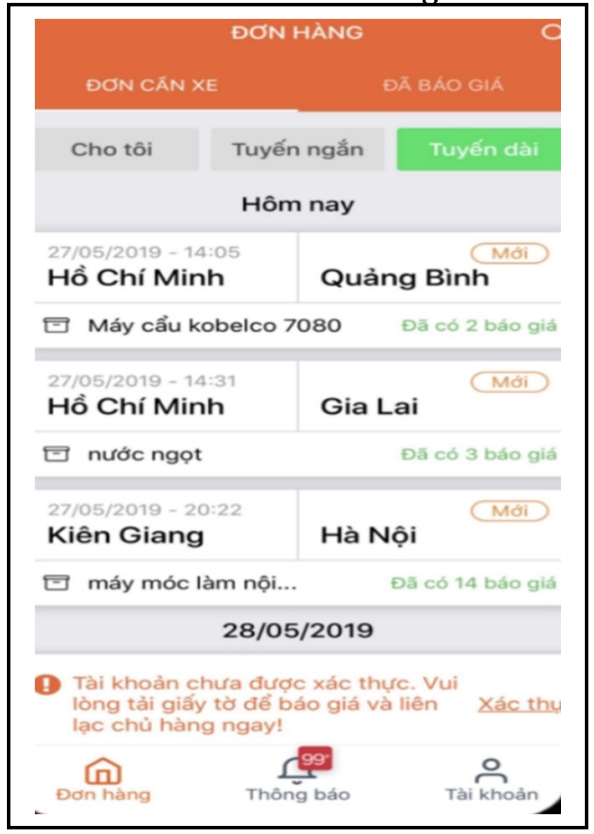
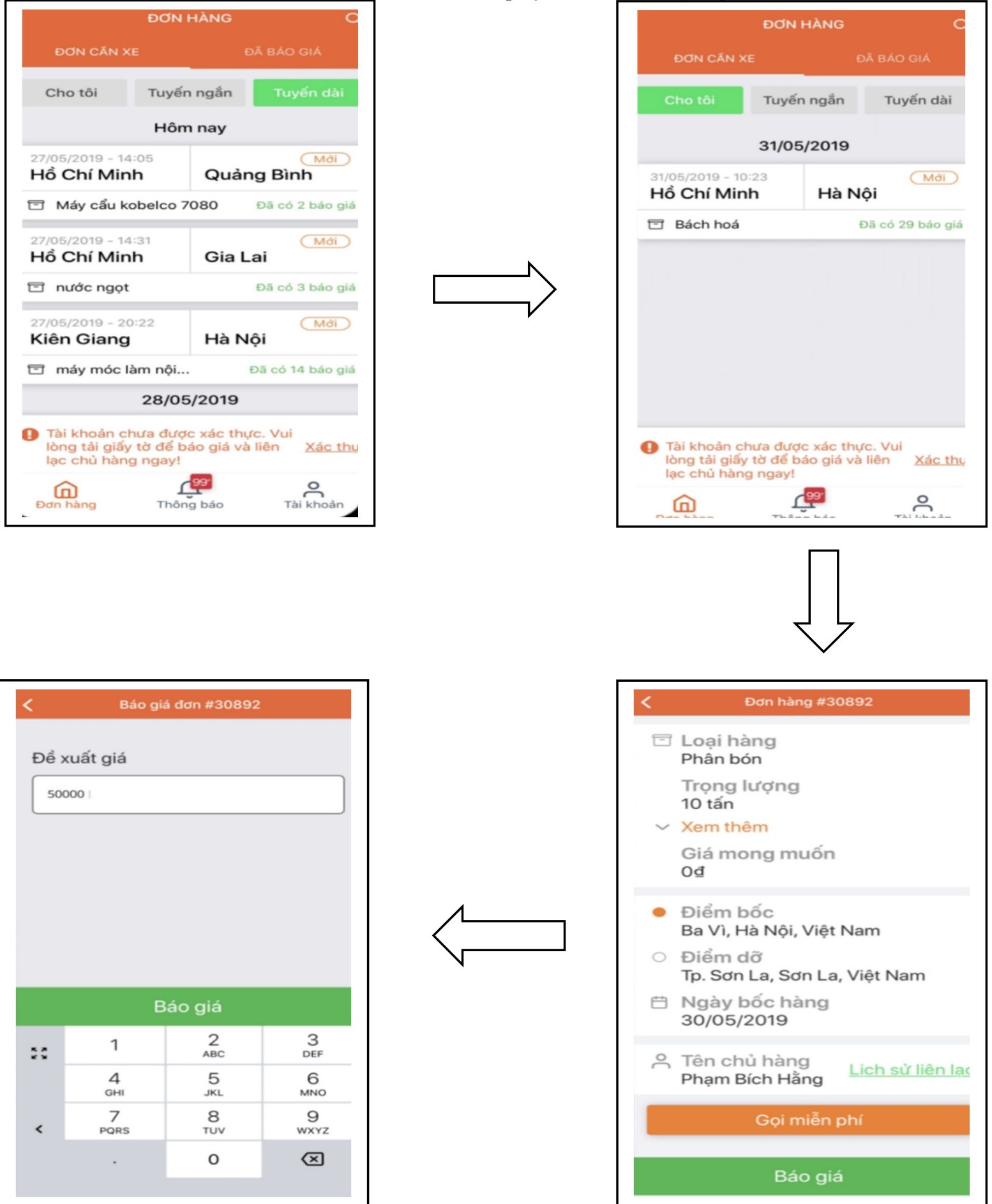

Source: Author made

After the quotation, if the customer agrees, the truck owner will conduct some follow-up operations to receive the order, when receiving and loading the vehicle, the vehicle owner click on the item: "Tôi đã bốc hàng". At the end of the transaction, after the vehicle owner has delivered the goods to the customer, the vehicle owner clicks the item: "Tôi đã dõ hàng" and completes the transaction. The implementation of these operations is to help LOGIVAN's staff keep track of the status of orders to update customers, creating the reputation and professionalism of the service. 
Figure 6. Vehicle owner receives order status
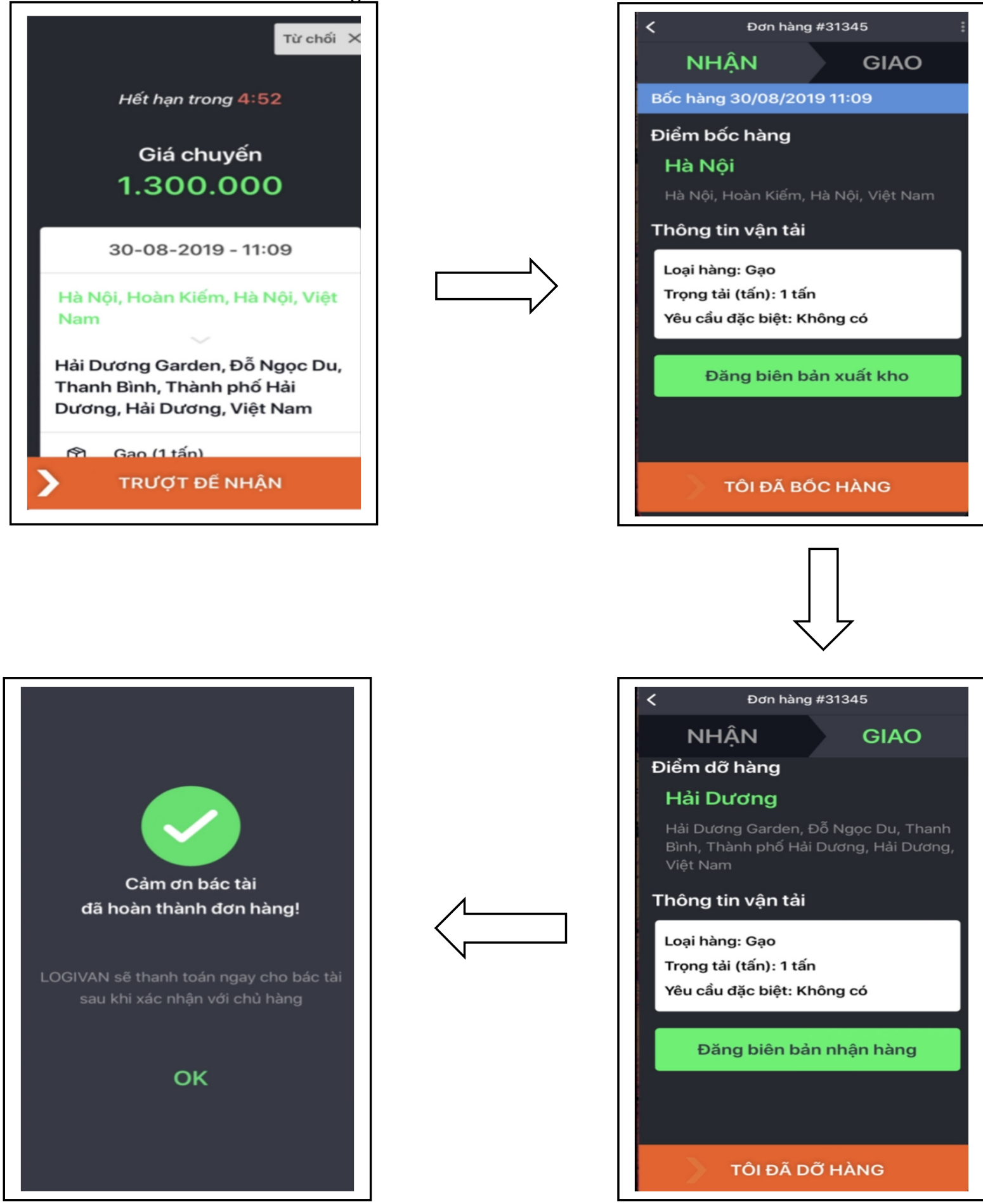

Source: Logivan

\section{CONCLUSION}

LOGIVAN intelligent transport model is an innovative transport model of Vietnamese people, aiming at the goal of transport optimization, bringing sustainable development to the national transport network.

With the development of services on two fundamental solutions: LOGIVAN Chủ hàng and LOGIVAN Chủ xe, LOGIVAN has solved the problem of empty return for businesses, saving costs for customers and increasing income for vehicle owners. Simple to use and performed on personal mobile devices, LOGIVAN ensures maximum convenience for users. Applying LOGIVAN smart transport model is a new direction, consistent with the development of Logistics services in Vietnam, bringing high economic efficiency, contributing to encourage 
businesses to innovate and apply science and technology in production and business.

However, the development of Industry 4.0 requires the LOGIVAN team to constantly research and innovate services to suit social needs in certain stages. In particular, it is necessary to absorb the achievements of artificial intelligence, the internet of things, big data... for digital technology solutions, business operating innovation, contributing to the sustainable development of national logistics services in the future. Besides, the issues of international cooperation for improvement, technology transfer, scaling and operating markets are important requirements in the coming time.

\section{REFERENCES}

[1] The Prime Minister of Vietnam (2017), Decision No. 200/QD-TTg approving the action plan to enhance competitiveness and develop Vietnam's logistics service until 2025, Hanoi.

[2] Donal F. Wood, Logistics Business, https://www.britannica.com/topic/logistics-business\#ref528537

$$
\text { National }
$$

Assembly

(2005),

Commercial

Law, Hanoi.https://moj.gov.vn/vbpq/Lists/Vn\%20bn\%20php\%20lut/View_Detail.aspx?ItemID=18140

[4] Government Portal of the Socialist Republic of Vietnam, http://chinhphu.vn/portal/page/portal/chinhphu/NuocCHXHCNVietNam/ThongTinTongHop/dialy

[5] Ministry of Industry and Trade (2018), Vietnam Logistics Report 2018, Hanoi.

[6] T.H. Pham (2019), Developing Logistics services in Vietnam, Finance Magazine. http://tapchitaichinh.vn/nghien-cuu-trao-doi/phat-trien-nganh-dich-vu-logistics-tai-viet-nam-306129.html

[7] World Bank (2018), https://openknowledge.worldbank.org/bitstream/handle/10986/29971/LPI2018.pdf

[8] Chung Thanh (2019), 70\% of logistics enterprises are concentrated in Ho Chi Minh City and surrounding areas, Ho Chi Minh City Government Portal. http://tphcm.chinhphu.vn/70-doanh-nghiep-logistics-tap-trung-otphcm-va-vung-lan-can

[9] Website: https://www.logivan.com/ 